\title{
KONSEPSI RECHTERLIJK PARDON ATAU PEMAAFAN HAKIM DALAM RANCANGAN KUHP*
}

\author{
Adery Ardhan Saputro**
}

Lembaga Kajian MaPPI, Fakultas Hukum Universitas Indonesia, Depok

Gedung D Lantai 4 Fakultas Hukum Kampus Baru, Depok, Jawa Barat 16424

\begin{abstract}
The conception of Non-Imposing of a Penalty/Rechterlijk Pardon/dispensa de pena was unregulated in KUHP (Indonesia penal code). Conceptually, Rechterlijk Pardon is a modified form of "rigid legal certainty" to "flexible legal certainty". This paradigm of Rechterlijk Pardon is based on from several cases that's case have proven to commited crime, but his crimes are not feasible imposed a penalty. To respond the problem, RKUHP have created a new regulation (Judicial pardon), that's judge may determine in the judgement no punishment, where he deems this case not proper to imposed a penalty.
\end{abstract}

Keywords: rechterlijk pardon, KUHP, legal certainty.

\section{Intisari}

Konsepsi Non-Imposing of a Penalty/Rechterlijk Pardon/dispensa de pena merupakan suatu lembaga baru yang belum dikenal pada KUHP saat ini. Secara konseptual Rechterlijk Pardon merupakan bentuk dari modifikasi atas kepastian hukum yang bersifat kaku, menuju kepastian hukum yang bersifat fleksibel. Hal ini berangkat dari beberapa perkara yang sebenarnya telah memenuhi rumusan delik tindak pidana, namun perbuatannya tidak layak untuk dijatuhkan pemidanaan. Merespon masalah tersebut, RKUHP membuat suatu rumusan baru dengan mengatur dimungkinkannya pemaafan hakim terhadap beberapa perkara yang tidak layak dijatuhkan pemidanaan.

Kata Kunci: rechterlijk pardon, KUHP, kepastian hukum.

\section{Pokok Muatan}

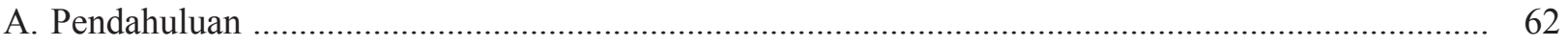

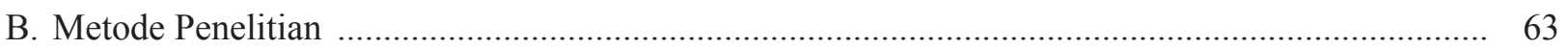

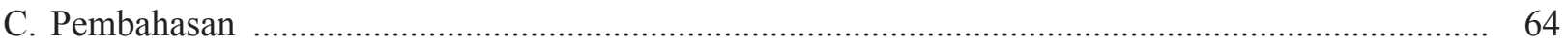

1. Pardon secara Konseptual, Filosofis dan Historis 64

2. Penerapan Non-Imposing of a Penalty/Rechterlijk Pardon sebagai Bentuk Alternatives Penal Measures to Imprisonment ............................................................................................... 66

3. Rechterlijk Pardon Sebagai Klep/Katup Pengaman (Veiligheids-Klep) dalam Pemidanaan ..... 69

4. Permasalahan Utama: Harmonisasi Pengaturan Rechterlijk Pardon pada RKUHP ke Depan ... 71

C. Penutup 


\section{A. Pendahuluan}

Majelis Hakim dalam memutuskan suatu perkara menurut KUHAP hanya memungkinkan 3 (tiga) kemungkinan, yaitu: ${ }^{1}$

1. Pemidanaan atau penjatuhan pidana; (veroordeling tot enigerlei sanctie);

2. Putusan bebas (vrij spraak);

3. Putusan lepas dari segala tuntutan hukum (onslag van recht vervolging).

Putusan bebas berarti terdakwa dijatuhi putusan bebas atau dinyatakan bebas dari tuntutan hukum atau acquittal. ${ }^{2}$ Berdasarkan Pasal 191 ayat (1)KUHAPputusan bebas dijatuhkanjika pengadilan berpendapat bahwa dari hasil pemeriksaan di sidang, kesalahan terdakwa atas perbuatan yang didakwakan kepadanya tidak terbukti secara sah dan meyakinkan. ${ }^{3}$ Oleh karenanya, suatu putusan bebas setidaknya didasarkan pada tidak memenuhi asas pembuktian menurut undang-undang secara negatif dan/atau tidak memenuhi asas batas minimum pembuktian. ${ }^{4}$

Sedangkan putusan lepas dari segala tuntutan hukum dijatuhkan menurut KUHAP "jika pengadilan berpendapat bahwa perbuatan yang didakwakan kepada terdakwa terbukti, tetapi perbuatan itu bukan merupakan suatu tindak pidana maka terdakwa diputus lepas dari segala tuntutan hukum". Oleh karena itu, apa yang didakwakan kepada terdakwa pada putusan lepas cukup terbukti secara sah dan meyakinkan, namun perbuatan yang didakwakan kepada terdakwa tidak bersalah (sengaja/alpa) atau tidak melawan hukum atau ada alasan pemaaf (feit d'excuse) . $^{5}$.

Dengan hanya tiga pilihan kemungkinan tersebut, maka timbul suatu pertanyaan mengenai bagaimana jika seorang terdakwa dinyatakan bersalah dan terbukti secara sah dan meyakinkan sesuai pasal $183 \mathrm{KUHAP}^{6}$, tetapi Majelis Hakim memandang perbuatan yang dilakukannya tidak harus dijatuhkan pemidanaan/Majelis Hakim memberikan maaf kepada terdakwa atas tindak pidananya? Maka apabila Majelis Hakim hanya mendasarkan pada tiga kemungkinan tersebut, muncul suatu permasalahan bagaimana cara agar Majelis Hakim dapat menjatuhkan suatu putusan tanpa pemidanaan (non imposing of a penalty). ${ }^{7}$

Permasalahan ini tidak akan terjadi di Negara Belanda setelah melakukan revisi WvS pada tahun 1983 melalui Undang-Undang 31-3-1983 yang telah memasukkan Pasal 9a berbunyi:

The judge may determine in the judgement that no punishment or measure shall be imposed, where he deems this advisable, by reason of the lack of gravity of the offense, the character of the offender, or the circumstances attendant upon the commission of the offense or thereafter. ${ }^{8}$

Oleh karena dimasukkanya Pasal 9a WvS, penyusun hukum acara pidana Belanda mengharmonisasikannya dengan memasukkan 4 (empat) kemungkinan dalam menjatuhkan suatu putusan

M. Yahya Harahap, 2006, Pembahasan Permasalahan dan Penerapan KUHAP, Sinar Grafika, Jakarta, hlm. $347-354$

Ibid., hlm. 347.

Pasal 191 ayat (1) Kitab Undang-Undang Hukum Acara Pidana (KUHAP) (Lembaran Negara Republik Indonesia Tahun 1981 Nomor 76, Tambahan Lembaran Negara Nomor 3209).

Pengertian dari “tidak memenuhi asas pembuktian menurut undang-undang secara negatif" adalah pembuktian yang diperoleh di persidangan tidak cukup membuktikan kesalahan terdakwa dan sekaligus kesalahan terdakwa yang tidak cukup terbukti, tidak diyakini oleh hakim. Sedangkan pengertian "tidak memenuhi asas batas minimum pembuktian" adalah terkait tidak terpenuhinya minimum 2 (dua) alat bukti di persidangan..

Andi Hamzah, 2008, Hukum Acara Pidana Indonesia, Sinar Grafika, Jakarta, hlm. 286-287.

Pasal 183 KUHAP berbunyi: "Hakim tidak boleh menjatuhkan pidana kepada seorang, apabila dengan sekurang-kurangnya dua alat bukti yang sah ia memperoleh keyakinan bahwa suatu tindak pidana benar-benar terjadi dan bahwa terdakwalah yang bersalah melakukannya"

Non imposing of penalty adalah dimana seoarang terdakwa terbukti bersalah, tetapi tidak dijatuhkan pemidanaan oleh Majelis Hakim. Pengertian dari non imposing of penalty/ Rechterlijk Pardon/ dispensa de pena mempunyai tujuan yang sama, yakni menyatakan seseorang terbukti secara sah dan meyakinkan, namun tidak menjatuhkan pemidanaan. Walaupun pemaknaan secara filosofis dari non imposing of penalty belum tentu didasarkan oleh konsepsi pemaafan hakim (bisa didasarkan hanya dari permasalahan penjara pendek, tetapi ketiganya mempunyai maksud yang sama untuk tidak menjatuhkan pidana sekalipun terdakwa terbukti)

Tim Penyusun Terjemahan, 1997, The American Series of Foreign Penal codes ( 30 Netheralands), Fred B Rothman \& Co, Colorado., hlm. 38. Lihat juga Andi Zainal Abidin dan Andi Hamzah, 2010, Pengantar Dalam Hukum Pidana Indonesia, Yarsif Watampone, Jakarta, hlm. 170-171. Terjemahan: Jika hakim menganggap patut berhubungan dengan kecilnya arti perbuatan, kepribadian pelaku atau keadaan-keadaan pada waktu perbuatan dilakukan, begitu pula sesudah itu ia menunjukkan keteladanan, ia (hakim) dapat menentukan di dalam putusan bahwa tidak ada pidana atau tindakan yang dijatuhkan. 
oleh Majelis Hakim: ${ }^{9}$

1. Pemidanaan atau penjatuhan pidana;

2. Putusan bebas (vrij spraak);

3. Putusan lepas dari segala tuntutan hukum (onslag van recht vervolging); dan

4. Putusan Pemaafan Hakim (Rechterlijk Pardon).

Latar belakang dimasukkannya konsep Rechterlijk pardon, ${ }^{10}$ menurut Prof. Nico Keizer ialah banyaknya terdakwa yang sebenarnya telah memenuhi pembuktian, akan tetapi jika diajatuhkan suatu pemidanaan akan bertentangan dengan rasa keadilan. ${ }^{11}$ Atau dapat dikatakan jika dijatuhkan pemidanaan, maka akan timbul suatu benturan antara kepastian hukum dengan keadilan hukum. Sebelum tahun 1983 apabila terjadi permasalahan di atas, Majelis Hakim akan secara "terpaksa" harus menjatuhkan pidana sekalipun sangat ringan. ${ }^{12}$ Dari penjelasan demikian terlihat bahwa Pasal 9A WvS Belanda, pada hakikatnya merupakan "pedoman pemidanaan" yang dilatabelakangi oleh ide fleksibilitas untuk menghindari kekakuan. Daput pula dikatakan bahwa adanya pedoman pemaafan hakim itu berfungsi sebagai suatu katup/ klep pengaman (veiligheidsklep) atau pintu darurat (noodeur).

Sebenarnya bagi beberapa negara, konsep lembaga pemaafan hakim terdengar asing. Hal ini dikarenakan konsepsi pardon/clemency pada umumnya terletak pada kekuasaan eksekutif, bukan pada yudisial. ${ }^{13}$ Penempatan pardon/ clemency pada kekuasaan eksekutif juga dianut oleh negara Indonesia dengan bentuk amnesti, tetapi peletakkanya pada lembaga yudisial merupakan hal yang baru dan sedikit janggal. ${ }^{14}$ Oleh karenanya, pada pembahasan berikutnya, penulis akan membahas pardon/clemency secara konseptual, filosofis, dan historis.

\section{B. Metode Penelitian}

Dilihat dari bentuknya, penelitian ini termasuk penelitian Yuridis Normatif yaitu suatu penelitian yang bertujuan untuk menjelaskan dan menganalisa mengenai "Konsepsi Rechterlijk Pardon/Pemaafan Hakim dalam RKUHP." Terkait dengan hal diatas, yang menjadi fokus kajian utama dalam tulisan ini adalah mengkaji bagaimanakah Filosofis, historis serta pengaturan di sistem negara luar mengenai Rechterlijk Pardon/ Pemaafan Hakim.

Dilihat dari tipologinya, penelitian ini termasuk ke dalam penelitian deskriptif. Penelitian deskriptif adalah penelitian yang menggambarkan, menjelaskan, dan menganalisa mengenai Filosofis, historis serta pengaturan di sistem negara luar mengenai Rechterlijk Pardon/Pemaafan Hakim.

Data yang digunakan dalam penelitian ini ialah data sekunder. Data sekunder yang digunakan terdiri dari bahan hukum primer, bahan hukum sekunder, dan bahan hukum tersier. Bahan hukum primer adalah bahan hukum penelitian yang diperoleh dari peraturan perundang-undangan serta yurisprudensi maupun putusan pengadilan. Bahan hukum primer yang digunakan diantaranya Rancangan Kitab Undang-Undang Hukum Acara Pidana (RKUHAP) tahun 2014, Rancangan Kitab Undang-Undang Hukum acara Pidana, edisi 2012, Rancangan Kitab Undang-Undang Hukum Pidana edisi revisi 2015, Undang-Undang Nomor 1

T.P. Marguery, 2008, Doctoral Thesis Unity and diversity of the public prosecutot services in Europe: A Study of the Czech, Dutch, French, and Polish System, Disertasi, Fakultas Hukum Universitas Gronigen, Gronigen.

10 Lembaga baru ini memberikan kewenangan kepada hakim untuk memberi maaf pada seseorang yang bersalah melakukan tindak pidana yang sifatnya sangat ringan (tidak serius), dan /atau mempunyai keadaan ringan atas perbuatannya. Pemberian maaf ini dicantumkan dalam putusan hakim dan tetap harus dinyatakan bahwa terdakwa terbukti melakukan tindak pidana yang didakwakan kepadanya. Lihat Tim Penyusun RKUHP, 1991, Laporan Kegiatan Tim Pengkajian/Rancangan Undang-Undang Bidang Hukum Pidana Bagian Penjelasan, Penyusun RKUHP 1991, Jakarta, hlm. 5.

11 Nico Keizer dan D. Schaffmeister, 1990, Beberapa Catatan Tentang Rancangan Permulaan 1998 Buku I KUHP Baru Indonesia,Driebergen/ Valkenburg, Belanda, hlm.55.

12 Tim Penyusun RKUHP, 2015, Naskah Akademis RKUHP (Edisi 25 Februari 2015), Badan Pembinaan Hukum Nasional, Jakarta, hlm. 23.

13 Hanya sedikit negara yang mengatur Judicial Pardon, diantaranya: (1) Belanda, (2) Perancis, (3) Portugal, (4) Greenland, (5) Somalia, (6) Uzbekistan, dan (7) Yunani. Terkait pembahasan komparatif akan dikaji pada poin berikutnya.

14 Baru dimasukkan pada RKUHP tahun 1991-1992, yang sebelumnya belum diatur akan lembaga pemaafan hakim , sedangkan diberbagai negara pengaturan akan lembaga pemaafan hakim juga baru dimasukkan pada sekitaran tahun 1970. 
Tahun 1946 tentang Peraturan Hukum Pidana, dan Resolusi No 10 Tahun 1976 tentang "alternative penal measures to imprisonment Department of Ecosoc, Fourth UN Congress 1970.

Bahan hukum sekunder adalah bahan hukum penelitian yang diperoleh dari bahan bacaan hukum, yang dalam hal ini adalah buku, jurnal ilmiah, wawancara, dan makalah. Selanjutnya, bahan hukum tersier, yakni kamus besar bahasa Indonesia dan kamus bahasa Belanda-Indonesia.

Alat pengumpul data yang digunakan dalam penelitian ini adalah studi kepustakaan, dan untuk membantu menganalisis permasalahan. Studi kepustakaan dilakukan adalah dengan mengumpulkan bahan bacaan hukum yang terkait dengan Hukum Pidana Materil terutama dalam halkonsep lembaga pemaafan hakim. Metode analisis data dengan kualitatif, sehingga hasil penelitian berbentuk deskriptif-analistis.

\section{Pembahasan}

\section{Pardon secara Konseptual, Filosofis dan} Historis

Terminologi "forgiveness", "pardon", "mercy", clemency"15, "indemnity", dan "amnesty" tidak mempunyai pemaknaan yang kaku (fleksibel), ${ }^{16}$ namun secara garis besar dapat dimaknai dengan suatu pengampunan atas perbuatan yang bertentangan dengan legalitas perundangan, dengan dasar keadilan di mayarakat ${ }^{17}$. Sebenarnya secara historis hubungan antara pemidanaan dengan pemaafan (pardon) telah berlangsung sejak code of Ham- murabi. ${ }^{18}$ Pada code of Hammurabi mengatur akan suatu keseimbangan antara kekakuan legalitas dengan keadilan yang muncul dari masyarakat.

Pada masa Romawi, para tentara Romawi yang dianggap telah berjasa,, akan diberikan suatu imunitas dan pemaafan oleh para penguasa Romawi (royal authority). ${ }^{19}$ Penggunaan lembaga pemaafan pada masa Romawi digunakan secara sewenangwenang tanpa adanya indikator yang jelas, bahkan digunakan untuk memperkuat kewenangan imperium. Hal ini juga terjadi pada masa Han sebagai emperor Cina yang menggunakan lembaga pemaafan untuk seolah-olah memperbolehkan segala tindakan yang bertentangan dengan peraturan demi memperkuat pengaruh kaisar Han. ${ }^{20}$

Penggunaan lembaga pemaafan secara berlebihan, juga terjadi pada negara-negara common law. Salah satu perkara yang menghebohkan ialah pemberian amnesty/pardon oleh King of Charles II kepada Danby selaku prime minister, yang pada saat itu akan di-impeach oleh Parlemen Inggris karena suatu perbuatan tindak pidana. ${ }^{21}$ Kejadian ini menjadi sangat aneh karena pada tatanan monarki konstitusional, raja sebagai kepala negara tidak pernah menolak suatu impeachment yang dilakukan parlemen terhadap perdana menteri, tidak hanya itu penggunaan lembaga pemaafan raja untuk menghentikan impeachment menjadi sesuatu yang tidak masuk akal. Selain itu, King of Charles II juga pernah menjual pardons/amnesty seharga 2 (dua) shilling ${ }^{22}$ kepada setiap pelaku tindak pidana. Perbuatan ini sangat ditentang oleh Luther dan

15 Clemency diartikan dengan Pemidanaan yang dibatalakan, sedangkan pardon mempunyai pengertian kejahatan yang dimaafkan. Kendati dua hal tersebut mempunyai tujuan yang sama, tetapi pemaknaannya sedikit berbeda. Lebih lanjut lihat Mardjono Reksodiputro, 2013, Renungan Perjalanan reformasi Hukum (Ambivalensi dan Ketidakpastian hukum), Komisi Hukum Nasional, Jakarta, hlm. 148.

16 Lembaga pengampunan bukanlah suatu upaya hukum (rechtsmiddel) dalam hukum acara pidana, dan arena itu bukanlah suatu hak yang diberikan kepada terdakwa maupun penuntut umum. Sedangkan pengampunan mempunyai tujuan lain, yakni meniadakan pelaksanaan akibat hukum pidana, apabila hukum yang berlaku untuk suatu peristiwa hukum tertentu dapat menimbulkan ketidakadilan. Oleh karenanya, meskipun asasnya adalah hukum harus ditegakkan, dalam hal yang khusus diberikan maaf (forgiveness) dengan tidak melaksanakan hukum. Lebih lanjut lihat Mardjono Reksodiputro, 2009, Menyelaraskan pembaharuan Hukum (Pemberian Abolisi Dalam perkara Mantan presiden Soeharto Tidak logis: benarkah itu), Komisi Hukum Nasional, Jakarta, hlm. 67.

David Tait, "Pardons in Perspective: The Role of Forgiveness in Criminal Justice", U.S, Federal Sentecing Report, Vol.2, Tahun 2001.

King, "Hammurabis Code of LSaws”, http://eawc.evansville.edu/anthology/hammurabi.htm. diakses 13 Oktober 2015.

Rolph, 1978, The Queen's pardon, Littlehampton Book Services Ltd., Southampton, hlm. 83.

20 McKnight, 1981, The Quality of mercy strained: Wrestling the Pardoning Power from the King, University Press of Hawaii, Honolulu, hlm. 238.

$21 \quad$ Ibid., hlm. 21

22 Shilling adalah koin yang digunakan oleh United Kingdom pada jaman dahulu untuk melakukan perdagangan yang jika ditaksir senilai 20 pounds. 
para reformis hukum, yang memandang lembaga pemberian maaf merupakan mesin pencari uang, bukan pencari keadilan. ${ }^{23}$

Kejadian-kejadian di atas telah menimbulkan suatu pandangan klasik yang beranggapan bahwa pardon/amnesty hanya merupakan intervensi dari lembaga eksekutif terhadap pengadilan. Pandangan ini berangkat dari sejarah yang hanya meletakkan lembaga pemaafan pada kekuasaan eksekutif semata. Peletakkan intervensi kekuasaan eksekutif pada lembaga yudisial, ternyata menimbulkan protes di Perancis setelah pasca revolusi Perancis. ${ }^{24}$ Maka pada saat revolusi Perancis, lembaga pemaafan telah dihapuskan kerana akan bertentangan dengan alam demokrasi yang mendasarkan segala peraturan melalui lembaga legislatif.

Namun penghapusan atas lembaga pemaafan/ pardon/amnesty tidak berlangsung lama di negara Perancis. Lembaga pemaafan kembali dihidupkan, namun dengan model yang berbeda dengan menyesuiakan pada konsep separation power. Pada konsep ini lembaga pemaafan tidak hanya kepada eksekutif tetapi juga pada lembaga yudisial, sesuai dengan prinsip pemisahan kekuasaan. Salah satu contoh kasus klasik yang terkenal ialah pardons et Chatiments, yang pada saat itu juri sebagai bagian dari lembaga yudisial telah memberikan maaf kepada terdakwa yang terbukti, sehingga menghindarkan terdakwa pada penjatuhan hukuman mati (guillotine). ${ }^{25}$ Juri mempunyai suatu kekuasaan untuk menghubungkan antara perbuatan yang dilakukan terdakwa dengan faktor-faktor yang melandasi dilakukannya perbuatan, sehingga sekalipun secara bukti sudah mencukupi tetapi dapat dimaafkan. ${ }^{26}$

Sebenarnya modifikasi lembaga pemaafan yang sebelumnya hanya di eksekutif, namun sekarang berada pula di lembaga yudisial telah pula sejalan rekomendasi dari Komisi Para Menteri Dewan Eropa (Resolusi No.10/1976 tanggal 9 Maret 1976). ${ }^{27}$ Resolusi tersebut mengamanatkan agar diberikannya hak kepada Hakim untuk dapat tidak menjatuhkan pidana apapun terhadap delikdelik ringan. Pada poin 3 huruf a berbunyi sebagai berikut:

To study various new alternatives to prison with a view to their possible incorporation into their respective legislations and in particular:

a. to consider the scope for penal measures which simply mark a finding of guilt but impose no substantive penalty on the offender [...].

Sebenarnya sebelum keluar resolusi tersebut, sistem peradilan pidana Perancis juga telah memperkenalkan lembaga pemaafan Hakim pada tanggal 11 Juli 1975 melalui Undang-Undang Nomor 75-624 KUHAP Perancis (CCP) yang mengatur tentang the declaration of guilt without imposing a penalty. ${ }^{28}$

Selain negara Perancis dan Belanda ${ }^{29}$, Sistem

\footnotetext{
Hewitt, 1978, The queen's Pardon, Casell, London, hlm. 174.

David Tait, Op.cit., hlm. 3.

Gruel, 1994, Pardons et Chatiments: Les Jures Francais Face aux Violences Criminelles, Nathan Publishing, Paris, hlm. 35.

Lihat perkara pembunuhan Anne Pasquio di Perancis.

Pasal 3 huruf a Resolusi No. 10 Tahun 1976 tentang Alternative Penal Measures to Imprisonment.

Barda Nawawi Arief, 2013, Kapita Selekta Hukum Pidana, Citra Aditya Bakti, Bandung, hlm. 8.

Terdapat beberapa negara lainnya yang mengatur akan lembaga pemaafan hakim, yakni:

1. Negara Yunani mengatur tentang “non imposing of a penalty” dalam Pasal 302 ayat (2) dan Pasal 314 ayat (2) Penal code;

2. Negara bagian Greenland mengatur tentang "The court may abstain from iposing any sanction dalam Pasal 86 ayat (1) KUHP Greenland ;

3. Negara Somalia mengatur pada Pasal 147 ayat (1) dan ayat (2) yang berbunyi: "Where, in the case of an offence committed by a person under 18 or over 70 years of age, the applicable punishment is imprisonment for a maximum term of not more than three years or a pecuniary punishment, or both, the judge may abstain from entering conviction and grant judicial pardon where, having regard to the cirmcumstances referred do in article 110, he considers the offender will not commit any further offence. A judicial pardon shall extinguish the crime. "Selanjutnya pada pasal 147 ayat (2) KUHP Somalia mengatakan "a judicial pardon may not be granted more than once" ;

4. Negara Uzbekistan mengatur pada Pasal 70 yang berbunyi: A person, who committed a crime, may be discharged from penalty, in the instance if it is recognized that by the time of investigation or trial, due to changes of situation, or the person's irreproachable conduct, bona fide labor or study, has lost his socially dangerous nature." (Seseorang yang melakukan tindak pidana, dapat dibebaskan dari hukuman apabila dari perbuatan yang telah dilakukan, telah kehilangan bahaya sosialnya).

Lihat pula Muhammad Iftar Aryaputra, 2013, Pemaafan Hakim dalam Pembaharuan Hukum Pidana Indonesia, Tesis, Fakultas Hukum Universitas Indonesia, Depok.
} 
peradilan pidana Portugal juga mengatur mengenai non imposing of a penalty atau yang dikenal dengan dispensa de pena. ${ }^{30}$ Pengaturannya diatur pada Pasal 74 KUHP edisi 2006, yakni: ${ }^{31}$

(1) Terhadap delik yang diancama pidana penjara selama maksimum 6 bulan atau denda tidak lebih dari 120 denda harian;

(2) Sifat melawan hukumnya perbuatan dan kesalahan si pelaku sangat kecil (the unlawfulness of the act and the guilt of the agent are minute);

(3) Kerusakan/kerugian telah diperbaiki (The damages have been repaired), apabila ganti rugi belum dilaksanakan maka ditunda selama 1 tahun; dan

(4) Alasan-alasan pencegahan tidak menghalangi dispensasi pidana ini (Reasons of prevention do not oppose to the dispensation of penalty).

Berdasarkan penjelasan di atas, maka tujuan dispensa de pena tidak hanya untuk menghindari penjatuhan pidana penjara pendek, tetapi juga untuk mencegah pemidanaan yang tidak dibenarkan/ diperlukan dilihat dari sudut kebutuha, baik kebutuhan melindungi masyarakat maupun untuk rehabilitasi si pelaku. Dengan demikian, menurut penulis tujuan dari adanya lembaga pemaafan hakim terdapat dua hal, yakni:

1. Dalam rangka alternative penjara pendek (alternative penal measures to imprisonment); dan

2. Koreksi judisial terhadap asas legalitas (judicial corrective to the legality principle).

Terkait tujuan yang kedua, penulis telah membahasnya di atas, kendati akan membahas lebih mendalam pada bagian berikutnya. Namun penulis akan membahas terlebih dahulu mengenai tujuan yang pertama (alternatives penal measures to imprisonment).

\section{Penerapan Non-Imposing of a Penalty/ Rechterlijk Pardon sebagai Bentuk Alter- natives Penal Measures to Imprisonment}

Sejak tahun 1960an angka kriminalitas semakin tinggi dari waktu ke waktu di berbagai negara terutama eropa. Angka kriminalitas ini akan berbanding lurus dengan jumlah pelaku yang terbukti dan dijatuhi akan sanksi pemidanaan penjara. ${ }^{32}$ Hal ini menyababkan biaya finansial yang membludak dikarenakan jumlah narapidana yang terlalu banyak, sehingga akan menimbulkan inefisiensi pemidanaan. Pada tahun 1960an banyak akademisi maupun praktisi yang menentang adanya pemidanaan penjara terutama untuk "penjara pendek". Menurut para akademisi, apabila seseorang yang hanya dipidana atas tindak pidana ringan, maka pada saat selesai menjalani pidana akan menjadi "penjahat untuk tindak pidana kelas berat". Pandangan ini tidak lepas dari stigma atau label dari masyarakat yang menyatakan penjara adalah "sekolah tindak pidana". ${ }^{33}$

Sebenarnya pelaksanaan penjara pendek terhadap para pelaku tindak pidana telah menimbulkan suatu perdebatan di negara Austria dan Jerman pada tahun 1970. Efek negatif yang dimunculkan dari penjara pendek telah dikemukakan oleh Frans V. Liszt yang tidak mempercayai penjara pendek sebagi solusi penurunan angka recidivie rate. Menurut Frans jika dilakukan penjara pendek, maka tindakan-tindakan pemulihan tidak akan mampu berjalan, hanya akan menimbulkan negatif efek dari pemenjaraan. ${ }^{34}$ Secara garis besar, kritik terhadap penjara pendek terbagi atas dua golongan, kritik yang moderat dan kritik yang ekstrem ${ }^{35}$. Kritik moderat pada intinya masih mempertahankan pidana penjara, tetapi penggunaannya dibatasi (contoh: untuk penjara pendek). Sedangkan kritik yang ekstrim menghendaki dihapusnya seluruh

\footnotetext{
Enio Ramalho dan William Theudo Gilman, 2006, The Portuguese Penal Code, Verbo Juridico, Lisbon, hlm. 74.

Barda, Op.cit., hlm. 288.

Haen Marshall, 1987, Trends in Criminal Rates (Certainty of Punishment and severity of Punishment in Netherlands), Criminal Justice Policy Review, Amsterdam, hlm. 21-52

33 Hans Jorg Albrecht, "Sanction Policies and Alternative Measure to Incarcetion: European Experiences with Intermediate and Alternative Criminal Penalties", Makalah, 142 ND UNAFEI International Training corse visiting Experts Papers, Fuchu Jepang, Maret 2010.

Ibid.,

Barda, Op.cit., hlm. 27
} 
pidana penjara. Gerakan penghapusan pidana penjara penjara (prison abolition) ini terlihat dengan adanya International Conference on Prison Abolition (ICOPA) yang pertama kali pada tahun 1983 di Toronto. Hingga saat ini, ICOPA sudah melakukan international conferences sebanyak 15 kali.

Salah satu tokoh gerakan "prison abolition" yang menganut paham ekstrim adalah Prof Herman Bianchi, beliau mengatakan:

The institution of prison and imprisonment are to be for ever abolished, entirely and totally. No trace should be lift of this darkside in human history. ${ }^{36}$

Selanjutnya akademisi di Indonesia yang menaganut pandangan akan penghapusan pidana penjara secara ekstrim ialah Prof. Dr. Hazairin sejak tahun 1992 dalam tulisannya berjudul "Negara Tanpa Penjara". ${ }^{37}$ Sedangkan terhadap pandangan moderat terhadap pidana penjara dapat dikelompokkan dalam tiga kritik, yaitu dari sudut "strafmodus", "strafmaat", dan "strafsoort".38 Berkaitan dengan "penjara pendek" maka akan berhubungan dengan kritik atas "strafmaat", yakni melihat dari sudut lamanya pidana penjara, khususnya berniat membatasi atau mengurangi penggunaan penjara pendek. ${ }^{39}$ Terkait mengenai penjara pendek, dikemukakan oleh ahli Manuel Lopez Rey pada kongres PBB ke-4 (1970) bawa penjara pendek karena dengan waktu terbatas, akan meniadakan prospek-prospek rehabilitasi (excluded the prospect of rehabilitation). Beliau memperkirakan populasi penjara di dunia pada tahun 1970 rata-rata sehari antara 1,5-2 juta dan diantaranya sekitar 1,3 juta kurang dari 6 bulan dan dalam banyak hal kurang dari 3 bulan. ${ }^{40}$

Pemikiran dari Manuel Lopez Rey ternyata sejalan dengan hasil penelitian dari Freiburg Birth
Cohort study pada tahun 1970 di Negara Jerman, yang ditunjukkan melalui tabel berikut.

Tabel 1. Criminal Suspect in the 1970 Birth Cohort of German Males at the Age of 30 (Baden-Wuerttemberg, $\mathrm{N}=\mathbf{1 0 4 . 0 0 0})$

\begin{tabular}{ccc}
\hline N arrest & All criminal offences & N Suspect \\
\hline 1 & 31 & 31.834 \\
2 & 15 & 15.702 \\
3 & 10 & 10.428 \\
4 & 7 & 7.730 \\
5 & 6 & 6.157 \\
6 & 5 & 5.062 \\
7 & 4 & 4.310 \\
8 & 4 & 3.700 \\
9 & 3 & 3.238 \\
10 & 3 & 2.859 \\
$10-19$ & 1 & 1.096 \\
$20-49$ & 0,1 & 147 \\
$>49$ & 0,1 & \\
\hline
\end{tabular}

Sumber: Freiburg Birth Cohort Study, Tahun 1970.

Berdasarkan data di atas, ditemukan bahwa pelaku tindak pidana berat hanya sekumpulan orang, sedangkan pelaku yang paling banyak ialah pelaku yang hanya dipidana secara pendek. Selain itu dari statistik ini dapat disimpulkan bahwa pemidanaan penjara hanya layak untuk tindak pidana serius/ berat yang membutuhkan pemulihan yang jangka waktunya lama, sedangkan untuk pelaku tindak pidana ringan sebaiknya diselesaikan dengan alternatif pemidanaan.

Berangkat dari data di atas, pada awal tahun 1970 alternatif pemidanaan sudah mulai diperkenalkan dan diterapkan pada negaranegara Eropa. Kebijakan pemidanaan alternatif ternyata juga didukung oleh council of Europe dengan memberikan beberapa rekomendasi dan resolusi selama kurun waktu 50 tahun terakhir. Pada awal tahun 1965, The Council of Europe

\footnotetext{
36 Ibid., hlm. 28. Mengutip dari Herman Bainchi, "The startegies of Abolition", Makalah, International conferences on prison abolition, 24-27 Juni 1985, hlm 5. Terjemahannya yaitu, "Lembaga penjara dan pidana penjara harus dihapuskan untuk selama-lamanya dan secara menyeluruh. Tidak sedikit pun yang patut diambil dari sisi gelap di dalams sejarah kemanusiaan ini”.

37 Hazairin, 1981, Tujuh Serangkai Tentang Hukum, Bina Aksara, Jakarta, hlm. 9.

8 Barda, Op.cit., hlm.28.

Ibid.

40 Manuel Lopez Rey, “Alternative Penal Sanction”, Pidato, Fourth UN Congress, Brussels, 1970.
} 
mengeluarkan resolusi mengenai "suspended senteces, probation, dan beberapa alternative pemidanaan"(65,1), selanjutnya Council of Europe mengeluarkan resolusi lanjutan nomor $(76,10)$ yang merekomendasikan alternative penal measures to imprisonment. Selain itu dikeluarkan pula beberapa rekomendasi lanjutan pada tahun 1992 (Rec.R (92) 16), tahun 1999 (Rec.R (99) 22), tahun 2000 (Rec.R (2000) 22), dan tahun 2003 (Rec.R(2003) 22). ${ }^{41}$ Resolusi di atas mengamanatkan beberapa poin, yaitu: Pertama, pemidanaan penjara adalah the last resort dalam kebijakan pidana; Kedua, penjatuhan pidana kerja sosial harus sesuai dengan hak asasi manusia; Ketiga, penjatuhan pidana kerja sosial sebaiknya bertujuan untuk rehabilitasi dan intergrasi pelaku terhadap lingkungan sosial; dan Keempat, tersedia infrastruktur yang baik untuk pelaksanaan alternatives penal measures to imprisonment. Berdasarkan keputusan tersebut, maka negara-negara Eropa melaksanakan alternatif pemidanaan dengan berbagai macam, diantaranya: ${ }^{42}$

1. Alternatif penahanan

a. jaminan penangguhan penahanan;

b. electronic tagging dan pelacak- an.

2. Alternatif pemidanaan dengan tujuan menggantikan pemenjaraan secara penuh

a. penerapan denda;

b. penundaan pelaksaan pemidanaan secara penuh/sebagian;

c. kerja sosial;

d. kompensasi/restitusi;

e. penahanan rumah dan pengawasan elektronik (electronic tagging)

f. tindakan-tindakan ( contoh pada pelaku anak);

g. pemaafan hakim (judicial pardon).

3. Alternatif pemidanaan yang bertujuan untuk mengurangi lamanya pemidanaan

a. remisi/pelepasan bersyarat/penyesuaian pemidanaan.

Pelaksanaan atas alternatif pemidanaan "penjara pendek" dapat dikatakan sudah dapat efektif di beberapa negara Uni Eropa. Hal ini berdasarkan data statistik pada tahun 2006 mengenai banyaknya narapidana berdasarkan lamanya pemidanaan sebagai berikut:

Tabel 2. Narapidana Berdasarkan Lamanya Pemidanaan Tahun 2006

\begin{tabular}{lcccccc}
\hline Negara & $<\mathbf{6}$ bulan & $\mathbf{6 - 1 2}$ bulan & $\mathbf{1 - 3}$ tahun & $\mathbf{3 - 5}$ tahun & $>\mathbf{5}$ tahun & Seumur hidup \\
\hline Denmark & 3 & 16 & 17 & 21 & 20 & 1 \\
Swedia & 2 & 12 & 34 & 17 & 24 & 3 \\
Perancis & 5 & 16 & 21 & 11 & 34 & 1 \\
Inggris & 18 & 6 & 22 & 22 & 31 & 11 \\
Jerman & $7^{*}$ & 20 & 19 & 26 & 10 & 3 \\
Italia & 20 & 2 & 8 & 14 & 66 & 8 \\
Polandia & 3 & 17 & 44 & 14 & 15 & 1 \\
\hline
\end{tabular}

Sumber: Council of Europe Annual Penal Statistics, Tahun 2006.

$41 \quad$ Hans Jorg Albrecht, Op.cit., hlm. 29.

42 Hans Jorg Albrecht, 2001, Settlement Out of Court a Comparative Study of European Criminal Justice System Project 73, Hasil Penelitian, South African Law Commision, Afrika Selatan, hlm.20. Selanjutnya lihat pula Commision of The European Communities on the Approximation, Mutual Recognition and Enfoercement of Criminal Sanctions in the European Union (ANNEX II), Brussels tahun 2004. Lihat pula Thomson Reuters Aranzadi, "Study on Criminal Sanction Legislation and Practice in Representative Member States (Settlement of minor cases)", Makalah, European Union, Brussels, 2014. 
Berdasarkan tabel di atas, menggambarkan bahwa negara Denmark, Swedia, Perancis, Jerman, dan Polandia telah mengubah penjara pendeknya dengan berbagai bentuk alternatif pemidanaan. Sedangkan negara Inggris, dan Italia dapat dikategorikan negara yang masih belum dapat menghilangkan pelaksanaan "penjara pendek".

Mendasarkan akan hal-hal di atas, maka didapatkan beberapa kesimpulan, yakni:

1. Penjara pendek masih terjadi diberbagai negara terutama di Negara Eropa yang dianggap telah maju dalam Sistem Peradilan Pidananya

2. Perlu adanya penggunaan alternatif pemidanaanyanglebihefektif,sehingga tidak mengutamakan pemidanaan penjara yang membebankan anggaran negara yang terlalu besar.

3. Pelaksanan Resolusi Council of Europe yang mengamanatkan salah satunya Judicial pardon/ non imposing of penalty belum dilakukan secara maksimal oleh beberapa negara. Bahkan KUHP Indonesia saat ini belum mengatur akan alternatif pemidanaan.

\section{Rechterlijk Pardon Sebagai Klep/Katup Pengaman (Veiligheids-Klep) dalam Pemidanaan}

Dalam pandangan Prof Nico Keizer, lembaga pemaafan hakim mempunyai suatu tujuan sebagai katup/klep pengaman atau pintu darurat dalam suatu pemidanaan. Pandangan ini bisa digambarkan oleh penulis, merujuk pada kasus di Perancis pada tanggal 5 Maret tahun 2001 terhadap pelaku Anne Pasquio. ${ }^{43}$ Ringkasannya sebagai berikut: Anna Pasquio mempunyai tiga orang anak, yang salah satu anaknya berumur 10 tahun menderita autis akut, berdasarkan pengawasannya bahwa kondisi anak semakin kritis. Anna melihat anaknya betapa tersiksa dengan penyakit yang dialaminya. Oleh karena, didasarkan rasa kasih sayang maka Anna Pasquio memutuskan untuk membunuh anaknya dengan cara mendorong anaknya dari dermaga ke dalam air.

Perkara ini menjadi sangat menghebohkan saat itu di Perancis, penuntut umum menyadari bahwa pembunuhan yang dilakukannya memang dilakukan karena kasih sayang. Akan tetapi, tidak ada alasan bagi penuntut umum untuk menghentikan penyidikan dan penuntutannya, karena jika merujuk pada unsur tindak pidana maka semuanya sudah memenuhi. Sedangkan untuk diselesaikan secara settlement of court (penyelesaian perkara di luar sidang) juga tidak memungkinkan karena tindak pidana yang dilakukan adalah bukan tindak pidana ringan, serta usia dari terdakwa belum cukup tua sehingga tidak memenuhi syarat untuk tidak dilakukan penuntutan (not prosecute).

Apabila ini terjadi di Indonesia, dengan asumsi RKUHAP ${ }^{44}$ sudah disahkan, maka tetap tidak dapat menjawab permasalahan ini. Sebenarnya RKUHAP sudah mempunyai beberapa saringan untuk kasus-kasus yang seperti ini, yakni:

1. Pasal 42 ayat (2) dan (3) RKUHAP, mengenai kewenangan penuntut umum untuk menghentikan penuntutan demi kepentingan umum dan/atau dengan alasan tertentu; dan

2. Pasal 111 ayat (1) RKUHAP, mengenai kewenangan Hakim Pemeriksa Pendahuluan untuk menentukan layak atau tidaknya suatu pekara untuk dilakukan penuntutan ke pengadilan

Terkait saringan yang pertama, sebenarnya apakah mungkin terhadap Terdakwa Anne tidak dilanjutkan ke persidangan, namun hanya berhenti di tahap penuntutan? Apabila merujuk pada Pasal 42 ayat (2) jo. ayat (3) RKUHAP, berbunyi:

(2) Penuntut umum berwenang menghentikan penuntutan demi kepentingan umum dan/atau dengan alasan tertentu. 
(3) Kewenangan penuntut umum sebagaimana dimaksud pada ayat (2) dapat dilaksanakan jika:

a. Tindak pidana yang dilakukan bersifat ringan;

b. Tindak pidana yang dilakukan diancam dengan pidana penjara paling lama 4 (empat) tahun;

c. Tindak pidana yang dilakukan hanya diancam dengan pidana denda;

d. Umur tersangka pada waktu melakukan tindak pidana di atas 70 (tujuh puluh) tahun; dan/atau

e. Kerugian sudah diganti.

Sedangkan fakta hukum yang terjadi pada kasus Anna tidak dapat memenuhi persyaratan untuk dihentikan oleh penuntut umum, yakni:

1. Tindak pidana yang diancamkan ialah pembunuhan/pembunuhan berencana yang tidak termasuk tindak pidana ringan (lebih dari 4 tahun). Selain itu ancaman pidananya tidak hanya denda, namun juga terdapat ancaman pidana penjara;

2. Usia/umur dari Anna tidak mencapai usia 70 tahun

3. Tidak ada kerugian dalam tindak pidana tersebut, karena perbuatan pidananya berhubungan dengan kejahatan terhadap nyawa dan tubuh.

Dengan gambaran fakta hukum di atas, maka suatu hal yang amat tidak mungkin bagi Jaksa Penuntut Umum untuk menghentikan suatu penuntutan (not prosecute), dikarenakan tidak ada sama sekali syarat yang dapat terpenuhi untuk dilaksanakan Pasal 42 ayat (2) RKUHAP. Sehingga apabila terjadi di Indonesia, maka keadaannya akan sama seperti di Perancis, pasti perkara tersebut akan dilanjutkan oleh penuntut umum.

Selaniutnya, mengenai saringan yang kedua, bahwa dimungkinkannya perkara ini berhenti ditahap Hakim Pemeriksa Pendahuluan (HPP) menjadi sangat sulit. Hal ini dikarenakan, perbuatan yang dilakukan oleh terdakwa sebenarnya telah memenuhi unsur tindak pidana, bahkan terdakwa juga mengakui perbuatan yang dilakukannya. Oleh karenanya, jika ditinjau dari minimum pembuktian, seharusnya sudah memenuhi batas minimum pembuktian, sehingga sulit bagi Hakim Pemeriksa Pendahuluan untuk memberhentikan kasus ini. Oleh karenanya, tidak ada lagi jaring pengaman atas perkara-perkara yang seperti ini.

Hal ini juga terjadi di Perancis pada saat kasus ini berjalan, terjadi diskursus di antara para juri yang mengadili perkara. Para juri dan majelis Hakim berpandangan bahwa alat bukti yang dihadirkan sudah cukup untuk memenuhi minimum pembuktian, bahkan tidak ada alasan pemaaf dan pembenar yang dapat diberikan kepada Terdakwa. ${ }^{45}$ Sebenarnya negara Perancis sudah mempunyai pengaturan akan UU No. 75-624 KUHAP Perancis (CCP) yang mengatur tentang "the declaration of guilt without imposing a penalty", akan tetapi pengaturan tersebut hanya dapat berjalan untuk tindak pidana yang sifatnya ringan. Oleh karenanya, dengan terpaksa secara legalitas tidak ada alasan apapun untuk tidak menghukum terdakwa. ${ }^{46}$

Namun disisi lain, motivasi terdakwa untuk melakukan pembunuhan harus dijadikan suatu pertimbangan untuk tidak menjatuhkan pemidanaan. ${ }^{47}$ Akhirnya para juri dan Majelis Hakim sepakat untuk memberikan penjatuhan pidana yang sangat ringan sebagai satu solusi. Terdakwa

$45 \quad$ Ibid.

46 Di Indonesia terdapat beberapa kasus yang insignificant/ dapat menganggu rasa keadilan:

1. Kasus Minah atas tindak pidana pencurian Kakao dengan putusan pidana penjara selama 1 bulan 15 hari dengan amsa percobaaan 3 bulan

2. Kasus Sudarmadi atas tindak pidana pencurian sandal dengan putusan pidana penjara selama 3 bulan 17 hari.

3. Kasus Ellya Dado yang diputus secara progresif oleh Bismar Siregar yang mempertibangkan aspek settlemnt of court /islah diantara keduanya sebagai bentuk penghapusan dasar melawan hukum, mak terdakwa diputus lepas

Lihat lebih lengkap pada Muhammad Iftar Aryaputra, Op.cit., hlm. 120.

$47 \quad$ Ibid.

$48 \quad$ Ibid., hlm. 8 . 
dijatuhkan pidana penjara selama 3 tahun dengan penundanan bersyarat penuh (wholly suspended)/ pidana percobaan. ${ }^{48}$ Dapat dikatakan sebenarnya putusan ini melegakkan, tetapi tetap menyelesaikan atas kekauan legalitas yang seharusnya dapat menyikapi hal-hal seperti ini. Kejadian di perancis ini juga mengingat akan pendapat dari Prof Nico Keizer, yang mengatakan bahwa:

Sebelum adanya pasal pemaafan hakim, apabila dalam keadaan khusus hakim di Belanda berpendapat bahwa sesungguhnya tidak harus dijatuhkan pidana, tetapi hakim terpaksa harus menjatuhkan pidana walaupun sangat ringan. ${ }^{49}$

Kasus Anna Pasquio tidak akan menjadi suatu permasalahan yang besar, jika nantinya RKUHP memasukkan pengaturan akan lembaga pemaafan hakim. RKUHP edisi Bulan September 2015 telah memasukkan lembaga pemaafan dalam sistem pemidanaan, sesuai pasal 56 ayat (2) RKUHP:

Ringannya perbuatan, keadaan pribadi pembuat, atau keadaan pada waktu dilakukan perbuatan atau yang terjadi kemudian, dapat dijadikan dasar pertimbangan untuk tidak menjatuhkan pidana atau mengenakan tindakan dengan mempertimbangkan segi keadilan dan kemanusiaan.

Pengaturan ini memberikan kemungkinan untuk tidak menjatuhkan pidana terhadap terdakwa yang telah terbukti melakukan suatu tindak pidana. Namun terdapat beberapa pembatasan agar Majelis Hakim dapat menjatuhkan putusan bersifat Rechterlijk Pardon, yakni:

1. Ringannya perbuatan;

2. Ringannya keadaan pribadi pembuat dan/atau;

3. Ringannya keadaan pada waktu dilakukan perbuatan atau yang terjadi kemudian; dan

4. Dengan mempertimbangkan segi keadilan dan kemanusiaan.

Apabila merujuk pada empat unsur di atas, maka perbuatan Anna Pasquio yang melakukan pembunuhan terhadap anaknya karena dilandasi rasa sayang. Seharusnya tidak patut untuk dilakukan penghukuman, dikarenakan perbuatan yang dilakukan memenuhi ringannya keadaan pribadi pembuat dan memenuhi rasa keadilan dan kemanusian. Sehingga penulis dapat simpulkan Rechterlijk Pardon layaknya "jaring pengaman terakhir" dalam sistem peradilan pidana. Apabila digambarkan dalam suatu flowchart, maka akan didapatkan seperti ini:

\section{Bagan 1. Mekanisme Penyaringan Perkara yang Tidak Layak Dilakukan Pemidanaan}

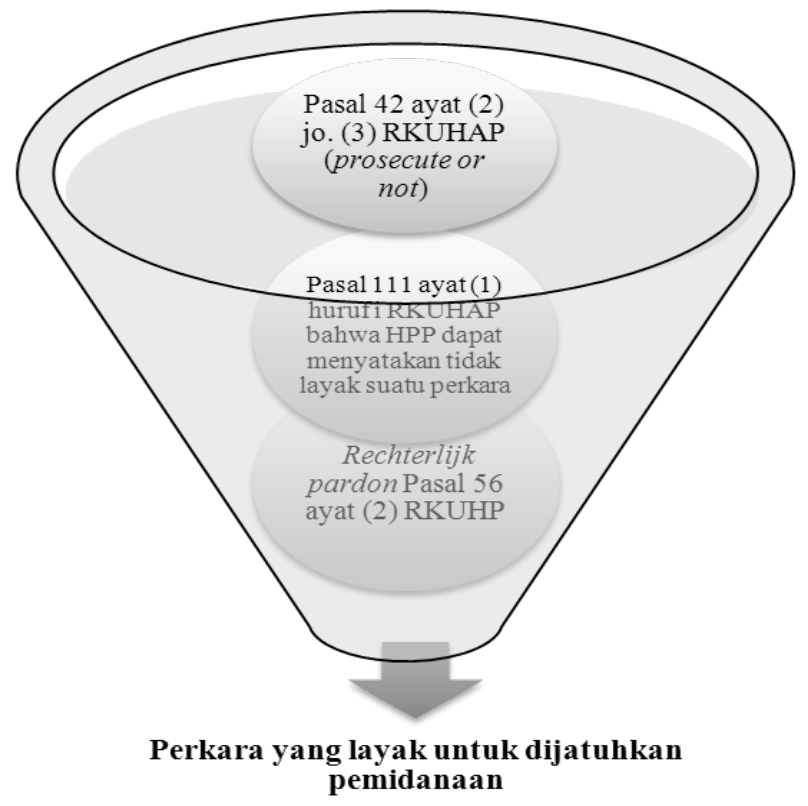

Sumber: diolah oleh Penulis.

Dari diagram di atas, lembaga pemaafan hakim dapat dijadikan sebagai jaring terakhir, apabila suatu perkara tidak tersaring di tahapan penuntutan dan hakim pemeriksa pendahuluan. Sehingga tepatlah, jika dikatakan lembaga pemaafan sebagai katup/klep pengaman (veiligheidsklep) atau pintu darurat (noodeur).

4. Permasalahan Utama: Harmonisasi Pengaturan Rechterlijk Pardon pada RKUHP ke Depan

Pengaturan akan Rechterlijk Pardon tidak dapat hanya diatur dalam RKUHP, karena RKUHP 
hanya memuat hukum pidana materil. Bahkan ketentuan pemaafan hakim tidak dikenal sebelumnya dalam KUHP saat ini. Oleh karenanya, pengaturan Rechterlijk Pardon harus diselaraskan dengan RKUHAP kedepannya. Sehingga pasal akan lembaga pemaafan hakim bukan hanya "pasal mati", yang tidak dapat diimplementasikan secara praktek di persidangan. Kekhawatiran ini muncul, apabila kritis mencermati pengaturan RKUHAP terkait kemungkinan bentuk-bentuk putusan yang dapat dijatuhkan pada seorang terdakwa.

Pertanyaan kritis yang muncul, jenis putusan seperti apa yang akan dijatuhkan terhadap terdakwa yang dipandang terbukti namun dimaafkan? Apabila kita mencermati Pasal 187 RKUHAP, jenis putusan akhir yang dapat dikeluarkan terbagi atas tiga macam, yaitu putusan pemidanaan, putusan lepas, dan putusan bebas. ${ }^{50}$ Sedangkan dalam perkara Rechterlijk Pardon yang terjadi ialah secara unsurunsur tindak pidana terbukti, tetapi tidak dijatuhkan pemidanaan. Oleh karena itu, pembahasan ini akan menjadi sangat menarik terkait jenis putusan apa yang cocok untuk dijatuhkan terhadap terdakwa yang diberikan Rechterlijk Pardon.

Apabila Majelis Hakim menjatuhkan putusan bebas, maka jelas bertentangan dengan Pasal 187 ayat (2) RKUHAP yang mensyaratkan untuk dapat dijatuhkan putusan bebas "tindak pidana yang didakwakan tidak terbukti secara sah dan meyakinkan". Dalam hal ini, Terdakwa memenuhi segala unsur yang didakwakan oleh penuntut umum, baik secara asas batas minimum pembuktian atau asas pembuktian menurut undang-undang secara negatif. Oleh karenanya, suatu kesalahan bagi Majelis Hakim apabila menjatuhkan putusan bebas terhadap terdakwa yang telah terbukti secara sah dan meyakinkan, namun dimaafkan.

Kemungkinan yang kedua mengkategorikan jenis putusan permaafan hakim sebagai putusan lepas (onstlag van alle rechtsvervolging). Ketentuan mengenai putusan lepas dalam RKUHAP sudah mengalami perbaikan. Pasal 187 ayat (3) RKUHAP menyatakan, "Jika hakim berpendapat bahwa perbuatan yang didakwakan kepada terdakwa terbukti, tetapi ada dasar peniadaan pidana, terdakwa diputus lepas dari segala tuntutan hukum" Dalam kemungkinan ini, maka permaafan hakim dianggap sebagai dasar peniadaan pidana. Dasar peniadaan pidana dalam RKUHP diklasifikasikan menjadi alasan pembenar dan alasan pemaaf.

Menurut Penulis, apabila mengkategorikan jenis putusan pemaafan hakim sebagai putusan lepas akan menjadi suatu permasalahan terhadap beberapa kasus tertentu yang tidak memenuhi kualifikasi dasar pembenar dan pemaaf pidana. Contohnya, kasus Nenek Minah yang mengambil buah kakao, apakah memenuhi dasar pembenar atau pemaaf? sehingga dapat dikategorikan sebagai putusan lepas. Sebaliknya, penulis berpandangan apabila seorang terdakwa sudah memenuhi putusan lepas, untuk apa Majelis Hakim harus memberikan pemaafan padahal putusan lepas sudah cukup bagi terdakwa untuk tidak dipidana. Sehingga menurut penulis kemungkinan yang kedua ini juga tidak tepat.

Terakhir kemungkinan yang ketiga ialah menjatuhkan putusan pemidanaan, tetapi tidak dijatuhkan pidana. Pandangan ini didasarkan dari pendapat Andi Hamzah yang menyatakan sebagai berikut:

Bahwa bentuk putusan dari permaafan hakim nantinya adalah putusan bersalah tanpa pidana. ${ }^{51}$

Pendapat dari Andi Hamzah tersebut senada dengan yang pernyataan Jeroen Chorus, et al., yang menyatakan bahwa, ${ }^{52}$ apabila hakim memutuskan untuk memberikan permaafan maka putusannya adalah bersalah tanpa pidana (a guilty verdict without punishment).

Terhadap pandangan ini mungkin bisa

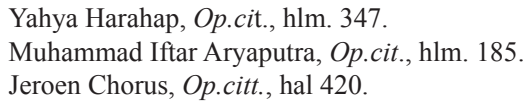


lebih masuk akal, tetapi jika kita meninjau ulang persyaratan muatan pada putusan pemidanaan pada Pasal 192 ayat (1) bahwa putusan pemidanaan harus memuat diantaranya:

Pernyataan kesalahan terdakwa pernyataan telah terpenuhi semua bagian inti dan unsur dalam rumusan tindak pidana disertai dengan kualifikasi dan pemidanaan atau tindakan yang dijatuhkan. ${ }^{53}$

Pada Pasal 192 ayat (1) huruf h terdapat suatu frase "disertai dengan kualifikasi dan pemidanaan atau tindakan yang dijatuhkan", pengaturan akan frase ini akan bertentangan dengan filosofis dari adanya lembaga pemaafan/Rechterlijk Pardon untuk tidak dijatuhkan suatu pemidanaan atau tindakan apapun. Pertanyaan yang muncul berikutnya, bagaimana jika Majelis Hakim tidak menjatuhkan suatu pemidanaan atau tindakan apapun? Merujuk pada Pasal 192 ayat (2), bahwa:

Apabila ketentuan sebagaimana dimaksud pada ayat (1) huruf a, huruf $b$, huruf $c$, huruf $d$, huruf e, huruf $f$, huruf $h$, huruf $j$, huruf $k$, huruf I, atau huruf $\mathrm{M}$ tidak dipenuhi, putusan batal demi hukum.

Dari pada Pada Pasal 192 ayat (2) dapat ditangkap bahwa jika tidak dijatuhkan pemidanaan atau tindakan, maka putusannya batal demi hukum. Sehingga putusan yang berjenis lembaga pemaafan tersebut, tidak dapat dinyatakan mempunyai kekuatan hukum. Dengan demikian, dari ketiga kemungkinan putusan pada RKUHAP, tidak ada jenis putusan yang dapat dijatuhkan kepada Terdakwa yang diberikan Rechterlijk Pardon.

Maka dari itu, apabila RKUHAP yang nantinya disahkan tidak mengatur secara khusus akan Rechterlijk Pardon, maka konsepsi lembaga pemaafan hanya akan menjadi pasal tumpul yang tidak akan digunakan oleh majelis Hakim. Hal ini dikarenakan, RKUHAP tidak memberikan pengaturan secara teknis, bagaimana Rechterlijk Pardon bukan hanya sekedar konseptual semata, namun dapat diaplikasikan pada praktek.

Berbeda dengan Indonesia, di Belanda pengaturan akan Rechterlijk Pardon ternyata tidak hanya disikapi oleh hukum pidana materiil saja, tetapi juga oleh hukum acara pidananya. Hakim pidana di negara Belanda dapat menjatuhkan 4 (tiga) bentuk putusan final, yakni: ${ }^{54}$
1. Putusan Bebas (vrijspraak);
2. Putusan Lepas (ontslag van alle rechtsvervolging);
3. Putusan Pemidanaan (veroordeling tot enigerlei sanctie); dan
4. Putusan Pemaafan Hakim (rechterlijk pardon).
Oleh karenanya, Majelis hakim/hakim dapat menjatuhkan putusan pemaafan hakim yang memang mempunyai tipe/bentuk yang berbeda/ khusus dibandingkan tiga putusan yang lainnya. Hal ini dikarenakan putusan pemaafan hakim bukan bagian dari putusan bebas, lepas, maupun pemidanaan, tetapi berbeda mempunyai kekhususan tersendiri.

Selain itu, RKUHAP juga tidak mengatur, apakah terhadap putusan pemaafan hakim dapat diajukan banding atau kasasi? Menurut penulis tidak menjadi masuk akal apabila putusan rechterlijk pardon dapat diajukan banding atau kasasi, karena seharusnya sifat dari putusan rechterlijk pardon bersifat final. Hal ini juga yang diatur pada Negara Belanda, bahwa putusan rechterlijk pardon. Tidak dapat diajukan banding maupun kasasi. Dengan demikian, kekhususan pengaturan ini semakin menunjukkan bahwa putusan rechterlijk pardon mempunyai tipikal yang berbeda dengan jenis putusan yang lainnya. 
Tabel 3. Beberapa Pengaturan Terkait Putusan Rechterlijk Pardon di Criminal Procedure Code Belanda

\begin{tabular}{|c|c|}
\hline Pasal & Pengaturan \\
\hline Pasal 9a Criminal Code of Netherlands & $\begin{array}{l}\text { The judge may determine in the judgement that no } \\
\text { punishment or measure shall be imposed, where he deems } \\
\text { this advisable, by reason of the lack of gravity of the offense, } \\
\text { the character of the offender, or the circumstances attendant } \\
\text { upon the commission of the offense or thereafter. } \\
\text { Terjemahannya adalah : Lembaga pemaafan hakim dapat } \\
\text { dilakukan terhadap delik ringan dan/atau dari kepribadian } \\
\text { pelaku }\end{array}$ \\
\hline $\begin{array}{l}\text { Pasal } 353 \text { ayat (1) Criminal Procedure } \\
\text { Code of Netherlands }\end{array}$ & $\begin{array}{l}\text { In the case of application of section } 9 \text { a of the Criminal Code, } \\
\text { of imposition of a punishment or measure, of acquittal or } \\
\text { dismissal of the charges, the District Court shall, subject to } \\
\text { application of section 94, give a decision on seized objects } \\
\text { whose return has not been ordered. This decision shall be } \\
\text { without prejudice to any person's right in regard of the } \\
\text { object. } \\
\text { Terjemahannya adalah menjelaskan mengenai kedudukan } \\
\text { barang/objek yang disita pada putusan Rechterlijk Pardon. }\end{array}$ \\
\hline $\begin{array}{l}\text { Pasal } 359 \text { ayat } 4 \text { Criminal Procedure Code } \\
\text { of Netherlands }\end{array}$ & $\begin{array}{l}\text { In the application of section } 9 \text { a or section } 44 \text { a of the Criminal } \\
\text { Code, the judgment shall state the special reasons which } \\
\text { led to the decision. Terjemahannya adalah: Terkait putusan } \\
\text { Rechterlijk Pardon, maka Majelis Hakim/hakim wajib } \\
\text { memberikan alasan khusus pada pertimbangan putusannya. }\end{array}$ \\
\hline $\begin{array}{l}\text { Pasal } 402 \text { ayat (2) huruf a Criminal } \\
\text { Procedure Code of Netherlands }\end{array}$ & $\begin{array}{l}\text { Appeal may be filed against judgments concerning minor } \\
\text { offences, rendered by the District Court as final judgment } \\
\text { or in the course of the hearing, by the public prosecutor } \\
\text { with the court which rendered the judgment, and by the } \\
\text { defendant who was not acquitted of the entire indictment, } \\
\text { unless in this regard in the final judgment: } \\
\text { a.. under application of section 9a of the Criminal Code, a } \\
\text { punishment or measure was not imposed. Terjemahannya: } \\
\text { Terkait putusan Rechterlijk Pardon tidak dapat dilakukan } \\
\text { banding) }\end{array}$ \\
\hline $\begin{array}{l}\text { Pasal } 427 \text { ayat (2) huruf a Criminal } \\
\text { Procedure Code of Netherlands }\end{array}$ & $\begin{array}{l}\text { Appeal may be filed against judgments concerning minor } \\
\text { offences, pronounced by the Courts of Appeal by the Public } \\
\text { Prosecution Service attached to the court which rendered } \\
\text { the judgment, and by the defendant, unless in this regard in } \\
\text { the final judgment: } \\
\text { a. under application of section } 9 \text { a of the Criminal Code, a } \\
\text { punishment or measure was not imposed, or [... ]. } \\
\text { Terjemahan: Terkait putusan Rechterlijk Pardon tidak dapat } \\
\text { dilakukan kasasi. }\end{array}$ \\
\hline
\end{tabular}

Sumber: diolah oleh Penulis.

\section{Penutup}

Bertolak dari hasil kajian di atas, penulis dapat mengambil beberapa kesimpulan, yaitu lembaga Pemaafan, merupakan suatu elemen penting untuk menjawab permasalahan-permasalahan yang tidak dapat diakomodir hanya dengan 3 (tiga) jenis putusan (bebas, lepas, dana pemidanaan). Selain itu, lembaga pemaafan dapat dipandang sebagai "penjaga gawang terakhir" atas suatu perkara yang mengganggu keadilan di masyarakat atau dapat 
dikatakan sebagai pintu darurat/klep pengaman dari adanya sistem peradilan pidana yang tidak tepat guna.

Akan tetapi, perlu ada penambahan materi dalam RKUHAP terkait dengan permaafan hakim. Hal ini dilatarbelakangi sampai saat ini, belum ada pasal khusus yang mengatur mengenai ketentuan formil permaafan hakim dalam RKUHAP. Dengan tidak adanya ketentuan formilnya dalam RKUHAP, maka dirasakan ketentuan permaafan hakim tidak lengkap. Bentuk putusan dari permaafan hakim adalah putusan salah tanpa pidana (a guilty verdict without punishment), hal ini belum diatur dalam RKUHAP, sehingga ada kemungkinan mengkategorisasi putusan lepas (onstlag) sebagai konkretisasi dari permaafan hakim. Apabila ini tidak dilakukan, maka lembaga pemaafan hakim hanya akan menjadi pasal "mati" semata.

\section{DAFTAR PUSTAKA}

\section{A. Buku}

Arief, Barda Nawawi, 2013, Kapita Selekta Hukum Pidana, Citra Aditya Bakti, Bandung.

Abidin, Andi Zainal dan Hamzah, Andi, 2010, Pengantar Dalam Hukum Pidana Indonesia, Yarsif Watampone, Jakarta.

Gruel, 1994, Pardons et Chatiments: Les Jures Francais Face aux Violences Criminelles, Nathan Publishing, Paris.

Harahap, Yahya, 2006, Pembahasan Permasalahan dan Penerapan KUHAP, Sinar Grafika, Jakarta.

Hamzah, Andi, 2008, Hukum Acara Pidana Indonesia, Sinar Grafika, Jakarta.

Hewitt, 1978, The queen's Pardon, Casell, London. Hazairin, 1981, Tujuh Serangkai Tentang Hukum, Bina Aksara, Jakarta.

Keizer, Nico dan Schaffmeister, 1990, Beberapa Catatan Tentang Rancangan Permulaan 1998 Buku I KUHP Baru Indonesia, Driebergen/ Valkenburg, Belanda.

Marshall, Haen, 1987, Trends in Criminal Rates (Certainty of Punishment and severity of Punishment in Netherlands), Criminal Justice Policy Review, Amsterdam.

McKnight, 1981, The Quality of mercy strained: Wrestling the Pardoning Power From the King, University Press of Hawaii, Honolulu.

Ramalho, Enio dan Gilman, William Theudo, 2006, The Portuguese Penal Code, Verbo Juridico, Lisbon.

Reksodiputro, Mardjono, 2013, Renungan
Perjalanan reformasi Hukum (Ambivalensi dan Ketidakpastian hukum), Komisi Hukum Nasional, Jakarta. 2009, Menyelaraskan Pembaharuan Hukum (Pemberian Abolisi dalam Perkara Mantan Presiden Soeharto Tidak Logis: Benarkah Itu), Komisi Hukum Nasional, Jakarta.

Rolph, 1978, The Queen's Pardon, Littlehampton Book Services Ltd., Southampton.

Tim Penyusun RKUHP, 1991, Laporan Kegiatan Tim Pengkajian/Rancangan Undang-Undang Bidang Hukum Pidana Bagian Penjelasan, Penyusun RKUHP 1991, Jakarta.

Tim Penyusun Terjemahan, 1997, The American Series of Foreign Penal codes (30 Netheralands), Fred B Rothman \& Co., Colorado.

Tim Penyusun RKUHP, 2015, Naskah Akademis RKUHP (edisi 25 Februari 2015), Badan Pembinaan Hukum Nasional, Jakarta.

\section{B. Artikel Jurnal}

Tait, David, "Pardons in Perspective: The Role of Forgiveness in Criminal Justice", U.S, Federal Sentecing Report, Vol.2, Tahun 2001.

\section{Makalah}

Albrecht, Hans Jorg, "Sanction Policies and Alternative Measure to Incarcetion: European Experiences with Intermediate and Alternative Criminal Penalties", Makalah, 
$142^{\text {nd }}$ UNAFEI International Training corse visiting Experts Papers, Fuchu Jepang, Maret 2010.

Bainchi, Herman, "The startegies of Abolition", Makalah, International Conferences on Prison Abolition, 24-27 Juni 1985

Rey, Manuel Lopez, "Alternative Penal Sanction", Pidato, Fourth UN Congress, 1970.

Aranzadi, Thomson Reuters, "Study on Criminal Sanction Legislation and Practice in Representative Member States (Settlement of minor cases)", Makalah, European Union, Brussels, 2014.

\section{Tugas Akhir}

Marguery, T.P, 2008, Doctoral Thesis Unity and Diversity of the Public Prosecutor Services in Europe: A Study of the Czech, Dutch, French, and Polish System, Disertasi, Fakultas Hukum Universitas Gronigen, Gronigen.

Aryaputra, Muhammad Iftar, 2013, Pemaafan
Hakim Dalam Pembaharuan Hukum Pidana Indonesia, Tesis, Fakultas Hukum Universitas Indonesia, Depok.

Albrecht, Hans Jorg, 2001, Settlement Out of Court a Comparative Study of European Criminal Justice System Project 73, Hasil Penelitian, South African Law Commision, Afrika Selatan.

\section{E. Internet}

King, "Hammurabis Code of LSaws", http://eawc. evansville.edu/anthology/hammurabi.htm, diakses 13 Oktober 2015.

\section{F. Peraturan Perundang-Undangan}

Kitab Undang-Undang Hukum Acara Pidana (KUHAP) (Lembaran Negara Republik Indonesia Tahun 1981 Nomor 76, Tambahan Lembaran Negara Nomor 3209).

Rancangan Kitab Undang-Undang Hukum Acara Pidana (RKUHAP) Tahun 2014. 